\title{
Adaptation of an instrument to classify neonatal patients into care categories
}

\author{
Adaptação de instrumento para classificação de pacientes neonatais em categorias de cuidados \\ Adaptación de un instrumento para clasificar pacientes neonatales en categorías de cuidados
}

How to cite this article:

Dini AP, Oliveira ACV, Almeida-Hamasaki BP, Mejias Quinteiro N, Carmona EV. Adaptation of an instrument to classify neonatal patients into care categories. Rev Esc Enferm USP. 2021;55:e03674. doi: https://doi.org/10.1590/S1980-220X2019033603674

\author{
Ariane Polidoro Dini ${ }^{1}$ \\ D Andrezza de Cassia Vannucci de \\ Oliveira $^{1}$ \\ (D) Beatriz Pera de Almeida- \\ Hamasaki $^{1}$

\section{(D) Norma Mejias Quinteiro²} \\ (D) Elenice Valentim Carmona ${ }^{1}$ \\ ${ }^{1}$ Universidade Estadual de Campinas, Faculdade \\ de Enfermagem, Campinas, SP, Brazil. \\ ${ }^{2}$ Universidade Estadual de Campinas, Faculdade \\ de Ciências Médicas, Campinas, SP, Brazil.
}

\begin{abstract}
Objective: To adapt and validate a patient classification instrument for neonatal units. Method: Methodological study, with adaptation of the Pediatric Patients Classification Instrument for neonatal patients. After content validation by judges, the instrument was tested for reliability, applied to 33 neonates by two nurses, simultaneously. To assess the agreement among nurses regarding the scores of each patient on the classification scale, an intraclass agreement coefficient was applied. To assess the agreement regarding the classification in care categories, the weighted Kappa coefficient was calculated. Results: The adapted instrument consisted of a total of nine indicators, with three care categories: high dependence on care, semiintensive care and intensive care. The Content Validity Index varied between 0.85 and 0.92 for items of the instrument. The intraclass agreement was 0.87 and the weighted Kappa for care categories was 0.56. Conclusion: An instrument that allows neonatal patients to be classified into care categories, with satisfactory reliability was validated to support the dimensioning of the nursing team.
\end{abstract}

DESCRIPTORS

Neonatal Nursing; Workload; Intensive Care Units, Neonatal; Validation Studies.

\author{
Corresponding author: \\ Ariane Polidoro Dini \\ Faculdade de Enfermagem, \\ Universidade Estadual de Campinas \\ Rua Tessália Vieira de Camargo, \\ 126, Cidade Universitária \\ CEP 13083-887 - Campinas, SP, Brazil \\ adini@unicamp.br
}

Received: 10/15/2019

Approved: 06/02/2020 


\section{INTRODUCTION}

The neonatal intensive care unit is the place where premature or term neonates are referred, who have clinical conditions that represent death risk. These patients are hospitalized for a sufficient period to recover from events related to pregnancy, childbirth and birth, as well as to reach parameters considered adequate for weight and vital signs ${ }^{(1)}$. Thus, the nursing team, coordinated by the nurse, is the professional core that acts most directly with the hospitalized patients, determining the care flow from admission, as well as building and strengthening the therapeutic bond with parents and other family members until discharge ${ }^{(1)}$.

The environment of the neonatal intensive care unit has a high technological density, which is used to provide support for balance and maintenance of the newborn's (NB) vital functions. The professionals inserted in this scenario work in search of harmony between human performance and the use of equipment, envisioning that the care remains humanized and safe ${ }^{(2)}$, while assisting the needs of the newborn and family. Thus, given the vulnerability of the patients and the frightening aspect that the environment full of bright and audible signs, equipment and devices can represent for parents, the literature has emphasized the relevance of nurses' performance in neonatal intensive care units to promote growth, physical and emotional development of newborns, especially premature infants, as well as the establishment of a bond with the family ${ }^{(3-4)}$. Family involvement has numerous advantages, including its commitment to adherence to treatments and health care strategies, reduction in the number of days of hospitalization, and the promotion of breastfeeding ${ }^{(4-5)}$.

In this context, among the challenges faced by the nursing team, are the growing plurality of institutional demands and the complexity of the patients. Therefore, the transpose of these challenges can be facilitated by the implementation of strategies linked to a care model that aims to meet both the needs of the NB and their family, quality, and safety standards.

In the work process that is developed in a neonatal unit, it is necessary that the needs of nursing professionals, the care profile of the unit and the quality of nursing care are in line. Thus, studies are needed to develop strategies and technological innovations to improve the work process and its results. Considering such demands, the Patient Classification Instrument (PCI) is a measurement scale for carrying out evidence-based practices (EBP) and obtaining reliable results that will be used in the decision-making and care management process $^{(6)}$. Therefore, it is a relevant technology to be used in neonatal units.

"The use of patient classification instruments makes it possible to characterize the inpatient units, and, in addition to supporting the dimensioning of personnel, it can support the forecasting of material and financial resources, promoting the improvement of competence and team involvement"(7).

Resolution No. 543, of April 18, 2017(8), of the Federal Nursing Council (COFEN), which updates and establishes parameters for the Dimensioning of the Nursing Team
Professionals in the services/settings where nursing activities are carried out, referred a specific patient classification instrument for pediatric patients ${ }^{(7)}$. However, this instrument needs to be adapted for its application in neonatal units, due to the specificities of the care context, which differ from the original instrument. Thus, the development of this study was justified to provide a specific instrument for neonatal patients that can support decisions in the nursing care process, contemplating administrative aspects regarding human and material resources, with better precision. Thus, the aim of this study was to adapt and validate a patient classification instrument for neonatal units.

\section{METHOD}

\section{TYPE OF STUDY}

This is a methodological study for adaptation and validation of a measurement instrument, which was carried out in two sequential stages: after the written authorization of the author of the Pediatric Patient Classification Instrument (PPCI), written in Brazilian Portuguese, the instrument content was adapted and validated to the neonatal population; subsequently, the validated content was tested with application to the target audience to verify its reliability.

\section{Stage 1 - Adaptation of the PPCI for the CLASSIFICATION OF NEONATAL PATIENTS}

The $\mathrm{PPCI}^{(7)}$ is formed by a total of 11 indicators, each of which has four situations of care dependency, graded from one to four points, in an increasing way as to the demand for care. The instrument makes it possible to classify patients into five care categories: Minimal, Intermediate, High dependency, Semi-intensive and Intensive ${ }^{(7)}$.

The adaptation of the original instrument was based on the literature ${ }^{(1-2,5-7,9)}$, in Resolution No. 543, of April 18, 2017, from $\mathrm{COFEN}^{(8)}$, in addition to the clinical experience of the authors and experience in management of the first author. Three meetings were held between two authors, each lasting three hours, so that the content of the original instrument was modified to better contemplate the specificities of the neonatal patients. Then, the adapted instrument was analyzed by a third author with experience in teaching, research, and assistance in neonatal nursing.

\section{Stage 2 - Content validation OF THE ADAPTED INSTRUMENT AND TEST}

The content of the adapted instrument was validated by nurses, named judges. Content validity refers to the careful analysis of an instrument with the aim of verifying whether the proposed items and subitems represent what they want to measure. Such validity is determined by the representativeness of the content to be studied, by the correspondence degree between the indicators selected to constitute a multiple scale and its conceptual definition, considering wording, legibility, and clarity in the conceptualization. Regarding the content of instruments, they are submitted to experts in the area of interest, which can result in the removal, modification or addition of items ${ }^{(10-11)}$. 


\section{SAMPLE DEFINITION}

There is no consensus in the literature on which criteria are most relevant for determining experts. In this study, nurses who met at least one of the following criteria were invited to participate: experience in validating instruments, experience in the use and/or development of measurement instruments, experience in neonatal unit management and clinical experience in neonatal unit. The only exclusion criterion was less than six months of professional experience. A number of five to ten judges ${ }^{(11)}$ was planned to validate the content of the adapted instrument. Subsequently, the validated instrument was applied to the target patients, with an intentional sample: all patients at the neonatal unit, on the day of the instrument test.

\section{Data collection}

A total of 15 judges were invited to participate, via email. After acceptance, they received the adapted instrument, along with guidelines for its evaluation and the Informed Consent Form (ICF). The instrument was delivered in print or via e-mail, depending on the judge's preference. It was requested to be returned in ten days. The total estimated time for the judge to assess the content of the instrument was 30 to 40 minutes.

The judges were asked to independently declare whether or not they agreed (agree/disagree) with the proposed title for the instrument, the description of the indicators (degree of activity, control measurement interval, oxygenation, food and hydration, excretion, hygiene and positioning care, drug therapy, bandages or skin care, participation, guidance of the mother/ family in the care of the newborn and the scale of classification in care categories) and the description of graduated situations, organized in ascending order as to the demand for nursing care activities. They were asked to make suggestions whenever they disagreed with the content. They were also asked to assess the pertinence and clarity of the items, in addition to the general scope of the instrument ${ }^{(11)}$, as described below:

a) Regarding pertinence, they analyzed whether the items reflected the concepts involved, whether they were relevant to the situation and adequate to the proposed objective ${ }^{(11)}$, indicating: " 1 " when they considered the item not relevant or not representative, "2" when considering that the item needs a major revision to be representative, "3" when there was a need for a small revision and "4" for an item considered relevant or representative;

b)As for clarity, they should evaluate the wording of each item, considering whether it expresses what it is desired to measure, faithfully translating the concept ${ }^{(11)}$. Thus, they could mark, for each item, from " 1 ", without clarity, to "4", for those considered very clear.

As for the scope, the instrument should be assessed as a whole, that is, each judge assessed whether the items allowed to obtain sufficient information to achieve its objective. This assessment can lead to the inclusion or exclusion of items, as needed ${ }^{(11)}$. In assessing the scope, the judges could mark: "1", when they considered it to be non-comprehensive; "2", when not very comprehensive; " 3 ", moderately comprehensive; or "4", when very comprehensive.
Subsequently, the instrument, validated by the judges and corrected according to their suggestions, was tested when it was applied, simultaneously and independently, by two nurses to all patients in a neonatal unit, with a total of 30 beds. This test aimed at assessing the agreement regarding the score attributed by the instrument to each patient, classifying it as: high dependence on care (NB stable from a clinical and nursing point of view), semi-intensive care (NB subject to clinical instability without imminent risk of death) or intensive care (NB with imminent risk of death, who needs permanent and specialized medical and nursing care).

\section{Data ANALYsis}

As for the content validation of the instrument, it was established that the agreement between the judges should be greater than or equal to $70 \%{ }^{(11)}$ with regard to the instrument's title, description of the items and graduated situations in each indicator. The Content Validity Index (CVI) was adopted to measure the proportion of judges who were in agreement on the criteria of relevance, clarity and scope, considering the use of the Likert type scale of 4 ordinal points. In this assessment, " 1 " represents the worst condition in terms of meeting the evaluated criterion and " 4 " refers to the best one ${ }^{(11)}$. The CVI was calculated by adding the answers " 3 " and " 4 " of each judge for each item of the instrument and dividing this sum by the total number of answers (which correspond to the number of judges who evaluated the item), as follows:

\section{$\mathrm{CVI}=\_$Number of responses " 3 " and " 4 " Total number of responses}

To evaluate the instrument as a whole, the sum of all CVIs calculated separately and divided by the number of items considered in the evaluation was used ${ }^{(11)}$. In this study, CVI equal to or greater than 0.80 was considered adequate ${ }^{(11-12)}$. When this index was not reached, the indicator was revised and sent back to the judges. Likewise, when the item description was approved (agree/disagree) less than $70 \%$, it was reviewed and sent for reassessment.

To assess inter-evaluators reliability or agreement between two nurses regarding the instrument scores, the weighted Kappa coefficient ${ }^{(13)}$ was calculated. This coefficient was categorized according to the strength of agreement ${ }^{(14)}$ : less than 0.0 is a poor agreement; 0.00 to 0.20 , negligible agreement; 0.21 to 0.40 , smooth agreement; 0.41 to 0.60 , moderate agreement; 0.61 to 0.80 , substantial agreement; while 0.81 to 1.00 means almost perfect agreement. To assess the agreement between the two nurses regarding the instrument's score, the intraclass correlation coefficient (ICC) ${ }^{(15)}$, was applied, for which it is suggested that values greater than 0.75 indicate good reliability. The nurses who performed the application of the instrument work in the unit where it was tested, are co-authors of this study and held a previous meeting with the authors with the highest academic degree. During the application of the instrument, which was simultaneous for each patient, there was no exchange of information between them. The ICF was waived by the Research Ethics Committee (REC) in relation to those 
responsible for the patients, as this is a study that would classify the unit's beds, without collecting sociodemographic or clinical data from neonatal and family patients.

For the analysis, one used the statistical software Statistical Analysis System (SAS), version 9.4, and Statistical Package for the Social Sciences (SPSS), version 22.

\section{ETHICAL ASPECTS}

This study was developed according to the recommendations of Resolution No. 466, of December 12, 2012, of the National Health Council on research with human beings, and approved by the Research Ethics Committee of the Universidade Estadual de Campinas, protocol 2. $421.756 / 2017$.

\section{RESULTS}

In the process of adapting the PPCI for the development of the NPCI, most of the original items were preserved, with the exception of the item of mobility and walking, since it does not suit the profile of the patients under study. Considering the consulted literature and the authors' experience, the descriptions of the indicators and the grading of situations related to care were substantially altered, aiming at adapting to the neonatal patient. In addition, the categories of minimum and intermediate care were excluded, as they do not apply to this type of patient ${ }^{(7)}$.

The content validation with the experts/judges took place over a period of two months: a total of seven judges completed the validation of the instrument, which meant a return of $46.7 \%$. For the adequacy of the content, two rounds with the judges were necessary. Of the seven judges, three were $\mathrm{PhDs}$, two were $\mathrm{PhD}$ students, one master and one management specialist. With regard to the area of activity, two of them work as lecturer, researcher and with extension education projects in the neonatal nursing area, one is a neonatal unit manager, two are assisting neonatal nurses and two judges were in an exclusive activity dedicated to the doctoral program in nursing. All of them had more than six months' experience in the area of interest: one to 19 years.

The results of the CVI of the indicators and care categories adapted from the NPCI are shown in Table 1 . The agreement of the judges regarding the definitions of the indicators and graduated situations is shown in Table 2.

Table 1 - Content validity index of the Neonatal Patient Classification Instrument - Campinas, SP, Brazil, 2018.

\begin{tabular}{lccc}
\hline Indicator & Relevance & Clarity & CVI* \\
\hline Mother's participation & 0.85 & 0.85 & 0.85 \\
Support network and maternal support & 1 & 0.57 & 0.78 \\
Degree of activity & 0.85 & 0.85 & 0.85 \\
Oxygenation & 1 & 0.71 & 0.85 \\
Food and hydration & 0.85 & 0.85 & 0.85 \\
Excretion & 0.85 & 0.85 & 0.85 \\
Body hygiene & 0.85 & 1 & 0.92 \\
Control measurement interval** & 1 & 0.83 & 0.92 \\
Drug Therapy** & 1 & 0.71 & 0.92 \\
Dressings or Skin Care & 1 & 1 & 1 \\
Care Categories & 0.85 & 0.85 & - \\
Total CVI of the instrument & - & 0.85 \\
\hline
\end{tabular}

* CVI - Content Validity Index.

** Indicators that required a second assessment due to $\mathrm{CVI}<0.80$.

Table 2 - Proportion of agreement between the judges regarding the content of the indicators and the graduated situations of the Neonatal Patient Classification Instrument - Campinas, SP, Brazil, 2018.

\begin{tabular}{lcc}
\hline Indicator & Agreement on definition & Agreement on graduated situations \\
\hline Mother's participation* & $83 \%$ & $83 \%$ \\
Support network and maternal support & $50 \%$ & $57 \%$ \\
Degree of activity & $85 \%$ & $85 \%$ \\
Oxygenation & $85 \%$ & $71 \%$ \\
Food and hydration* & $85 \%$ & $100 \%$ \\
Excretion & $85 \%$ & $85 \%$ \\
Body hygiene & $85 \%$ & $71 \%$ \\
Control measurement interval & $100 \%$ & $100 \%$ \\
Drug Therapy & $85 \%$ & $71 \%$ \\
Dressings or Skin Care & $85 \%$ & $100 \%$ \\
\hline
\end{tabular}

* Indicators that required a second assessment due to agreement $<70 \%$. 
In view of the results and suggestions of the judges, some changes were made to the content of the NPCI. In particular, the indicators "mother's participation" and "support network" were unified, because, as the judges pointed out, the indicator "support network and maternal support" would not favor assessing clearly what was proposed during the hospital stay. The modifications aimed at improving the clarity of the wording and the applicability of the instrument in neonatal units. The final content of the NPCI, after validated by the judges, is shown in Chart 1.

Chart 1 - Neonatal Patient Classification Instrument (NPCI), final version - Campinas, SP, Brazil, 2018.

\author{
DEGREE OF ACTIVITY (Reactivity to hygiene and comfort care and compatibility of the wake/sleep cycle with their need for food) \\ $1=$ Calm baby, alternating between vigil and sleep periods, waking up to feedings and hygiene and comfort care \\ $2=$ Sleepy baby in hygiene and comfort care, needs little encouragement to breastfeed \\ $3=$ Very sleepy baby, needs consistent and continuous nursing stimulation OR tearful baby \\ 4=Very angry baby OR tearful OR sedated OR non-reactive
}

CONTROL MEASUREMENT INTERVAL (Need for observation and control of data such as temperature, O2 saturation, heart or respiratory rate, capillary blood glucose)

$1=$ Control intervals greater than 5 hours

$2=$ Control intervals between 4 and 5 hours

$3=$ Control intervals between 2 and 3 hours

$4=$ Control intervals less than 2 hours

OXYGENATION (Possibility of the baby maintaining normal airway permeability, ventilation, and oxygenation)

$1=$ Spontaneous breathing, without the need for oxygen therapy or airway clearance

$2=$ Spontaneous breathing, requiring airway clearance by instillation of serum

$3=$ Spontaneous breathing, requiring airway clearance due to aspiration of secretions and/or need for oxygen therapy

$4=$ Ventilation (Non-Invasive or Invasive)

FOOD AND HYDRATION (Possibility of the baby receiving fluids and nutrients by ingestion or by enteral or parenteral infusion)

$1=$ Effective breastfeeding

$2=\mathrm{Via}$ oral by cup or bottle

$3=$ Via catheters (gastric, post-pyloric or gastrostomy) or need breastfeeding or oral assistance, with increased risk of aspiration

$4=$ Special assistance in breastfeeding/Translactation and/or Parenteral nutrition

EXCRETION (Baby's conditions for urinary and intestinal excretion)

$1=$ Excretion in diapers at intervals equal to or greater than 3 hours

$2=$ Excretion in diapers at intervals between 2 to 3 hours

$3=$ Excretion in diapers at intervals of less than 2 hours

$4=$ Excretion by Probes and/or stomata

HYGIENE CARE AND POSITIONING (Body hygiene care and baby positioning)

$1=$ hygiene care and positioning performed in a common crib with a baby at intervals equal to or greater than 3 hours

$2=$ hygiene care and positioning performed in a common crib that includes an immersion bath

$3=$ hygiene care and positioning performed in an incubator or heated crib with a stable baby in care

$4=$ hygiene care and positioning in minimal handling due to baby's instability in care

DRUG THERAPY (Baby's need to receive medication)

$1=$ No medication needed

$2=$ Topical, ocular and/or oral medications with a calm baby

$3=$ Parenteral, enteral, inhaled OR topical, ocular OR oral medication with agitated baby

$4=$ Continuous intravenous using an infusion pump

DRESSINGS or SKIN CARE (Dressings or care for protection, prevention, maintenance or restoration of cutaneous-mucous integrity) $1=$ Intact skin throughout the body area

$2=$ Need for LOW complexity care, such as: skin hydration, treatment of simple dermatitis, renewal of peripheral venous catheter fixation $3=$ Need for MEDIUM complexity care, such as dressings on wounds limited to the skin, drain inserts, tracheostomy OR gastrostomy

$4=$ Need for $\mathrm{HIGH}$ complexity care, such as care with a central venous catheter AND/OR disseminated dermatitis, debridement, complexes stoma

or wounds with visualization of muscle fascia, bone tissue or eviscerations

PARTICIPATION AND GUIDANCE OF THE MOTHER/FAMILY IN THE CARE OF THE NEWBORN (Performance and understanding of the mother or family regarding the orientations received and/or the provision of care consistent with the baby's needs)

$1=$ Mother/family member understands the orientations received, recognizes and manages to meet the baby's care needs during the preparation for hospital discharge

$2=$ Mother/family member understands the guidelines received and demonstrates availability to participate in the baby's care, under the guidance of nursing

$3=$ Mother/family member understands the orientations received, but demonstrates difficulties to participate in the baby's care and needs constant nursing assistance

4=Mother/family member demonstrates difficulties in understanding the orientations received and/or demonstrates unavailability to participate in the baby's care

\title{
CLASSIFICATION SCALE IN CARE CATEGORIES*
}

9 to 17 points: High dependence on care (NB stable from a clinical and nursing point of view)

18 to 26 points: Semi-intensive care (NB subject to clinical instability without imminent risk of death)

27 to 36 points: Intensive care (NB with imminent risk of death, needs permanent and specialized medical and nursing assistance)

*Care categories are obtained from the sum of the points assigned to each indicator 
The instrument was applied to a total of 33 hospitalized newborns, considering the 24 hours of care the day before the application. During simultaneous application, without talking to each other, two nurses added the points of the nine indicators for each patient and determined the care category for each of the newborns. Table 3 shows the agreement between the nurses regarding the scores attributed to patients, showing good reliability (0.87). On the other hand, table 4 shows the agreement regarding the care categories assigned to patients, with a moderate agreement $(0.65)$.

Table 3 - Inter-evaluator reliability of the Neonatal Patient Classification Instrument - Campinas, SP, Brazil, 2018.

\begin{tabular}{lccccccc} 
Judge & $\begin{array}{c}\text { Standard } \\
\text { deviation }\end{array}$ & Minimum & Q1 & Median & Q3 & $\begin{array}{c}\text { ICC* } \\
(\mathbf{9 5} \% \mathbf{C I})\end{array}$ \\
\hline Nurse A & 5.41 & 15 & 18 & 19 & 25 & 32 \\
Nurse B & 4.42 & 14 & 20 & 23 & 25 & 32 \\
\hline
\end{tabular}

* Intraclass correlation coefficient.

Note: $(n=33)$.

Table 4 - Values of weighted Kappa coefficient and confidence interval $(\mathrm{Cl})$ regarding the agreement on classification in care categories - Campinas, SP, Brazil, 2018.

\begin{tabular}{lccc}
\hline & & Nurse A & \\
\cline { 2 - 4 } Nurse B & High dependency & Semi-intensive & $\begin{array}{c}\text { Weighted Kappa } \\
(\mathbf{9 5} \% \mathbf{C I})\end{array}$ \\
\hline High dependency & 2 & 6 & 0 \\
Semi-intensive & 1 & 16 & 1 \\
Intensive & 0 & 1 & 6 \\
\hline
\end{tabular}

Note: $(n=33)$.

\section{DISCUSSION}

The adaptation and validation of an instrument previously built for another patient, the $\mathrm{PPCI}^{(7)}$, were guided by the analysis of indicators or areas of nursing care, considering the context of neonatal care. In the adaptation process, the indicator "Ambulation" of the original instrument ${ }^{(7)}$ was excluded because it does not represent an area of care for neonatal patients.

The exclusion of the categories of minimum and intermediate care occurred in line with national legislation ${ }^{(8)}$, which points, as a standard of nursing hours per day, a total of four hours for minimum care and six hours per day for intermediate care. This was considered impractical by the authors of this study, also supported by the literature cited by the authors of the original instrument ${ }^{(7)}$, since they show that in the category of minimum care there are patients older than 12 years old, while in the category of intermediate care there are patients older than seven years old.

Thus, in line with the researches that supported the construction of the original instrument ${ }^{(7-8,16)}$, the authors of this study considered that neonatal patients cannot be considered as minimal or intermediate nursing care. Thus, they should be classified into one of the three care categories: high dependency, semi-intensive or intensive, which was corroborated by the judges who evaluated the content of the proposed NPCI.

In national legislation ${ }^{(8)}$, the standard of nursing care hours for high dependency and semi-intensive care is the same: ten hours/day. The difference among the categories is the representativeness of the numerical proportion between nurses and nursing technicians, which is higher for semi-intensive care. In intensive care, the standard of nursing care hours is 18 hours/day ${ }^{(8)}$.

In the NPCI content validation process, the participation of judges with clinical, managerial and research experience in neonatology expanded the possibilities for analyzing and improving the instrument adapted to real situations of patient classification. Thus, it was necessary to send the instrument two times to the judges for the indicators to reach CVI $\geq$ 0.80 , as well as for the agreement regarding the definitions and situations described in the NPCI to be greater than $70 \%$. With the participants' suggestions and notes, NPCI took on its final version (Chart 1).

During content validation, some judges' suggestions could not be accepted because they disagreed with the concept of care demand ${ }^{(7-8,16-17)}$, when they considered only the time of assistance, without taking into account the complexity of care. Also considering the suggestions of the judges, there was a decision to exclude the indicator "Support network" and add the family member one, focusing on the process of preparing for discharge, which occurs throughout the entire hospitalization, valuing the time dedicated by the nursing team in orienting the family, in addition to optimizing the time of parents in the neonatal unit in a care centered also on the family ${ }^{(18-19)}$.

In the "food and hydration" indicator, parenteral nutrition requires care, such as exclusive venous access and good practices for preventing infection and ensuring patient safety ${ }^{(20)}$, making it more complex in relation to enteral nutrition, which, although of recognized complexity, it remained scored as three points and parenteral as four points. In adapting the "Excretion" indicator, unlike the patients of the original 
instrument $t^{(7)}$, it was decided to maintain different scores regarding the diaper change interval. Thus, the specificity of these patients was considered, as well as the highest score in clients using bladder catheters and stoma due to the complexity of nursing care to reduce the risk of infection, ensuring the dignity of the patient regarding the reduction of odors, maintenance of intact skin and delicate techniques for ostoma bags exchanges ${ }^{(21)}$, in addition to systematic emptying of the bladder catheter collection bag.

In this study, when applied by two nurses to 33 newborns, the NPCI showed good reliability as to the scores attributed to patients, which ranged from 15 to 32 points ( \pm 5.41 ), according to Nurse $A$, and 14 to 20 points $( \pm 4.42)$, according to Nurse B. Regarding the classification of patients in the care categories, it also showed a favorable result for its use, with a moderate agreement.

The NPCI proved to be easy to apply. For this type of instrument to be reliable, it must be easy to apply, comprehensive and validated, to avoid errors in measuring the phenomenon. Errors can happen when an instrument like this considers the care provided at the expense of those required by patients. Another important aspect that can lead to errors is to disregard the experience of professionals or indirect aspects of care, as well as different dimensions of nursing practice ${ }^{(22)}$.

The NPCI should be investigated in other studies, being applied in different neonatal units and nurses, with the possibility of restructuring it in order to subsidize the dimensioning of nursing team and the rethinking of the current ordinances that determine this dimensioning without a specific instrument for neonatal patients. The limitations of this study reside in the application in only one unit, as well as in the absence of an assessment of construct validity. Therefore, it is relevant to carry out studies that fill these gaps.

\section{CONCLUSION}

Based on the adaptation of the Pediatric Patient Classification Instrument for neonatal clients, the Neonatal Patient Classification Instrument was developed, which proved to be valid and reliable for the intended context. The adapted instrument makes it possible to classify neonatal patients into three care categories: high dependency on care, semi-intensive care, and intensive care. It consisted of a total of nine care indicators: Degree of activity; control measurement interval; Oxygenation, Food and hydration; Excretion; Hygiene care and positioning; Body Hygiene, control measurement interval, Drug therapy; Dressings or skin care; and Participation and guidance of the mother/ family member in the care of the newborn.

It is recommended to apply the instrument in neonatal intensive care units with different care profiles and to evaluate other psychometric properties of the instrument, such as construct validity and reliability.

\section{RESUMO}

Objetivo: Adaptar e validar instrumento de classificação de pacientes para unidades neonatais. Método: Estudo metodológico, com adaptação do Instrumento de Classificação de Pacientes Pediátricos para pacientes neonatais. Após a validação de conteúdo por juízes, foi realizado teste do instrumento quanto à confiabilidade, com aplicação em 33 neonatos por duas enfermeiras, de forma simultânea. Para avaliar a concordância entre as enfermeiras quanto aos escores de cada paciente na escala de classificação, aplicou-se coeficiente de concordância intraclasse. Para avaliar a concordância quanto à classificação em categorias de cuidado, foi calculado o coeficiente Kappa ponderado. Resultados: $\mathrm{O}$ instrumento adaptado ficou constituído por nove indicadores, com três categorias de cuidado: alta dependência de cuidados, cuidados semi-intensivos e cuidados intensivos. O Índice de Validade de Conteúdo variou entre 0,85 e 0,92 para itens do instrumento. A concordância intraclasse foi de 0,87 e o Kappa ponderado para as categorias de cuidado foi de 0,56. Conclusão: Foi validado um instrumento que permite classificar pacientes neonatais em categorias de cuidados, com confiabilidade satisfatória, para subsidiar o dimensionamento de pessoal de enfermagem.

\section{DESCRITORES}

Enfermagem Neonatal; Carga de Trabalho; Unidades de Terapia Intensiva Neonatal; Estudos de Validação.

\section{RESUMEN}

Objetivo: Adaptar y validar un instrumento para clasificar pacientes de unidades neonatales. Método: Se trata de un estudio metodológico, con la adaptación del Instrumento de Clasificación de Pacientes Pediátricos para pacientes neonatales. Después de la validación de contenido llevada a cabo por jueces, se testó el instrumento en cuanto a la fiabilidad, con dos enfermeras que lo aplicaron simultáneamente en 33 neonatos. Para evaluar la concordancia entre las enfermeras con respecto a las puntuaciones de cada paciente en la escala de clasificación, se aplicó un coeficiente de concordancia intraclase. Para sopesar la concordancia en la clasificación de las categorías de atención, se calculó el coeficiente Kappa ponderado. Resultados: El instrumento adaptado constaba de nueve indicadores, con tres categorías de cuidados: dependencia alta de cuidados, cuidados intermedios y cuidados intensivos. E1 Índice de Validez del Contenido oscilaba entre 0,85 y 0,92 para los elementos del instrumento. La concordancia intraclase era 0,87 y el Kappa ponderado para las categorías de atención, 0,56. Conclusión: Se validó un instrumento para clasificar a los pacientes neonatales en categorías de atención, con una fiabilidad satisfactoria para subvencionar el dimensionamiento del personal de enfermería.

\section{DESCRIPTORES}

Enfermeria Neonatal; Carga de Trabajo; Unidades de Cuidado Intensivo Neonatal; Estudios de Validación.

\section{REFERENCES}

1. Silva LG, Araújo RT, Teixeira MA. O cuidado de enfermagem ao neonato pré-termo em unidade neonatal: perspectiva de profissionais de enfermagem. Rev Eletr Enferm UFG. 2012;14(3):634-43. doi: https://doi.org/10.5216/ree.v14i3.12531

2. Nascimento VF, Silva RCR. Assistência de enfermagem ao recém-nascido pré-termo frente as possíveis intercorrências. Rev Enferm UFSM. 2014;4(2):429-38. doi: https://doi.org/10.5902/2179769210252 
3. Aguiar ASC, Mariano MR, Almeida LS, Cardoso MVL, Pagliuca LMF, Rebouça CBA. The nurses' perceptions regarding health promotion in the Intensive Care Unit. Rev Esc Enferm USP. 2012;46(2):428-35. doi: https://doi.org/10.1590/S0080-62342012000200022

4. Campos CJG, Murakami R. Importância da relação interpessoal do enfermeiro com a família de crianças hospitalizadas. Rev Bras Enferm. 2011;64(2):254-60. doi: https://doi.org/10.1590/S0034-71672011000200006

5. Mello DF, Lima RAG. Êxito técnico, sucesso prático e sabedoria prática: bases conceituais hermenêuticas para o cuidado de enfermagem à criança. Rev Latino Am Enfermagem. 2009;17(4):580-5. doi: https://doi.org/10.1590/S0104-11692009000400022

6. Abreu SP, Pompeu DA, Perroca MG. Use of patients' classification instruments: analysis of the Brazilian production of knowledge. Rev Esc Enferm USP. 2014;48(6):1111-8. doi: https://doi.org/10.1590/S0080-623420140000700020

7. Dini AP, Guiradello EB. Pediatric patient classification system: improvement of an instrument. Rev Esc Enferm USP. 2014;48(5):787-93. doi: http://doi.org/10.1590/S0080-6234201400005000003

8. Conselho Federal de Enfermagem. Resolução COFEN n.543/2017. Estabelece parâmetros para o Dimensionamento do Quadro de Profissionais de Enfermagem nos serviços/locais em que são realizadas atividades de enfermagem [Internet]. Brasília: COFEn; 2017 [citado 2019 set. 01]. Disponível em: http://www.cofen.gov.br/resolucao-cofen-5432017_51440.html

9. Malloch K, Meisel M. Patient classification systems: state of the science. Nurse Leader. 2013;11(6):35-7. doi: https://doi.org/10.1016/j. mnl.2013.09.008

10. Polit DF, Beck CT. The content validity index: are you sure you know what's being reported? Critique and recommendations. Res Nurs Health. 2006;29(5):489-97. doi: 10.1002/nur.20147

11. Coluci M, Alexandre N, Milani D. Construção de instrumentos de medida na área de saúde. Ciênc Saúde Coletiva. 2015;20(3):925-36. doi: https://doi.org/10.1590/1413-81232015203.04332013

12. Terwee CB, Prinsen CAC, Chiarotto A, Westerman MJ, Patrick DL, Alonso J, et al. COSMIN methodology for evaluating the content validity of patient-reported outcome measures: a Delphi study. Qual Life Res. 2018;27(5):1159-70. doi: https://doi.org/10.1007/s11136018-1829-0

13. Cohen J. Weighted kappa: nominal scale agreement provision for scaled disagreement or partial credit. Psychol Bull. 1968;70(4):213-20. doi: http://dx.doi.org/10.1037/h0026256

14. Landis JR, Kock GG. The measurement of observer agreement for categorical data. Biometrics [Internet]. 1977 [cited 2019 Sep 30];33(1):159-74. Available from: https://pubmed.ncbi.nlm.nih.gov/843571/

15. Portney LG, Watkins MP. Foundations of clinical research: applications to practice. 3th ed. Upper Saddle River: Pearson; 2009.

16. Dini AP, Fugulin FMT, Veríssimo MLÓR, Guirardello EB. Pediatric classification system: construction and validation of care categories. Rev Esc Enferm USP. 2011;46(3):574-9. doi: https://doi.org/10.1590/S0080-62342011000300004

17. Alghamdi MG. Nursing workload: a concept analysis. J Nurs Manag. 2016;24(4):449-57. doi: 10.1111/jonm.12354

18. Tipa Z, Wilson D, Neville S, Adams J. Cultural responsiveness and the family partnership model. Nurs Prax NZ. 2015;31(2):35-47.

19. O’Brien CK, Wasrren PL. Father's perceptions of neonatal nursing support. J Neonatal Nurs. 2014;20(5):236-41. doi: https://doi. org/10.1016/j.jnn.2013.11.002

20. Conselho Federal de Enfermagem. Resolução COFEn n. 453/2014. Aprova a Norma Técnica que dispõe sobre a Atuação da Equipe de Enfermagem em Terapia Nutricional [Internet]. Brasília: COFEn; 2014 [citado 2019 set. 30]. Disponível em: http://www.cofen.gov.br/ resolucao-cofen-no-04532014_23430.html

21. Schreiber ML. Ostomies: nursing care and management. Medsurg Nurs. 2016;25(2):127-30.

22. Bosco CS, Toma E, Oliveira SMJV, Belli MAJ. Reliability of an instrument to classify newborns according to care complexity. Rev Esc Enferm USP. 2013;47(4):788-93. doi: http://dx.doi.org/10.1590/S0080-623420130000400003 